Research

\title{
Reference values for exhaled nitric oxide (reveno) study Mario Olivieri ${ }^{1}$, Giorgio Talamini ${ }^{1}$, Massimo Corradi ${ }^{2}$, Luigi Perbellini ${ }^{1}$, Antonio Mutti ${ }^{2}$, Claudio Tantucci ${ }^{3}$ and Mario Malerba*3
}

\author{
Address: ${ }^{1}$ Department of Medicine and Public Health, University of Verona, Italy, ${ }^{2}$ Department of Clinical Medicine, Nephrology and Health \\ Sciences, University of Parma, Italy and ${ }^{3}$ Department of Internal Medicine, University of Brescia, Italy \\ Email: Mario Olivieri - mario.olivieri@univr.it; Giorgio Talamini - giorgio.talamini@univr.it; Massimo Corradi - massimo.corradi@unipr.it; \\ Luigi Perbellini - luigi.perbellini@univr.it; Antonio Mutti - antonio.mutti@unipr.it; Claudio Tantucci - tantucci@med.unibs.it; \\ Mario Malerba* - malerba@med.unibs.it \\ * Corresponding author
}

Published: 30 June 2006

Respiratory Research 2006, 7:94 doi:10.1 186/1465-9921-7-94

This article is available from: http://respiratory-research.com/content/7/I/94

(c) 2006 Olivieri et al; licensee BioMed Central Ltd.

This is an Open Access article distributed under the terms of the Creative Commons Attribution License (http://creativecommons.org/licenses/by/2.0), which permits unrestricted use, distribution, and reproduction in any medium, provided the original work is properly cited.

\begin{abstract}
Background: Despite the widespread use of fractional exhaled nitric oxide $\left(\mathrm{FE}_{\mathrm{NO}}\right)$ as a biomarker of airways inflammation, there are no published papers describing normal $\mathrm{FE}_{\mathrm{NO}}$ values in a large group of healthy adults.
\end{abstract}

Objective: The aim of this study was to establish adult $\mathrm{FE}_{\mathrm{NO}}$ reference values according to the international guidelines.

Methods: $\mathrm{FE}_{\mathrm{NO}}$ was measured in 204 healthy, non-smoking adults with normal spirometry values using the on-line single-breath technique, and the results were analysed chemiluminescently.

Results: The main result of the study was the significant difference in $\mathrm{FE}_{\mathrm{NO}}$ values between men and women, thus indicating that gender-based reference $\mathrm{FE}_{\mathrm{NO}}$ values are necessary. The $\mathrm{FE}_{\mathrm{NO}}$ levels obtained at expiratory flows of $50 \mathrm{ml} / \mathrm{s}$ ranged from 2.6 to $28.8 \mathrm{ppb}$ in men, and from 1.6 to 21.5 $\mathrm{ppb}$ in women.

Conclusion: We propose reference $\mathrm{FE}_{\mathrm{NO}}$ values for healthy adult men and women that could be used for clinical and research purposes.

\section{Background}

The presence of nitric oxide (NO) in exhaled air was first described in 1991 by Gustafsson et al.[1], and this was soon followed by a number of publications reporting high fractional concentrations of orally exhaled $\mathrm{NO}\left(\mathrm{FE}_{\mathrm{NO}}\right)$ in subjects with various pulmonary diseases [2]. $\mathrm{FE}_{\mathrm{NO}}$ is generally measured on line by having the subject blow directly into the analyser and obtaining immediate results [3], but breath can also be collected remotely into inert bags and analysed subsequently (off line) [3].
Although the pathophysiological meaning is still unclear [4], it has been demonstrated that NO levels in exhaled air are higher in asthmatics than in healthy subjects, increase during spontaneous or induced asthma exacerbations, and decrease after anti-inflammatory treatment [5].

Many studies have clearly demonstrated that a number of factors can affect $\mathrm{FE}_{\mathrm{NO}}$ values, and so the European Respiratory Society (ERS) and American Thoracic Society (ATS) established particular recommendations for exhaled and 
nasal NO measurements in 2005 [6] in order to allow the comparison of data from different research centres.

Clinicians and researchers seeking to apply $\mathrm{FE}_{\mathrm{NO}}$ measurements in everyday practice are obviously interested in knowing what are normal $\mathrm{FE}_{\mathrm{NO}}$ values in healthy subjects, but very few attempts have been made to establish such reference values, and experimental findings are usually only compared with those observed in the healthy controls recruited for any particular study. Buchvald et al. [7] have recently found that upper normal $\mathrm{FE}_{\mathrm{NO}}$ levels in children aged 4-17 years ranged from 15 parts per billion (ppb) in the youngest to $25 \mathrm{ppb}$ in adolescents, with a mean increase of 1 ppb per year. To the best of our knowledge, there are no published studies indicating similar reference values for adults.

The aim of this study was to establish reference adult $\mathrm{FE}_{\mathrm{NO}}$ values according to the international guidelines.

\section{Materials and methods}

\section{Study subjects and protocol}

This open-label study was conducted in three Italian centres (Brescia, Parma and Verona) and recruited local medical school students and colleagues, who were given a short description of the project, and the inclusion and exclusion criteria.

Healthy subjects were defined as individuals with normal spirometry values and without a history of any significant diseases. Furthermore, in accordance with the ATS/ERS guidelines [6], particular care was taken to avoid the known confounding factors that may affect $\mathrm{FE}_{\mathrm{NO}}$ measurements: in particular, smokers and ex-smokers were excluded; none of the volunteers was taking any drug or medication or had experienced a recent upper or lower airways infection, and none reported any clinical manifestation of allergic diseases or positive skin prick tests for common inhalant allergens.

The study was approved by the Ethics Committee of each centre and all of the participants gave their written informed consent.

\section{Fractional exhaled NO measurements}

Fractional exhaled NO ( $\left.\mathrm{FE}_{\mathrm{NO}}\right)$ was measured using a chemiluminescence analyser (CLD88, Ecomedics, Switzerland) whose lower and upper limit of detection (LOD) was respectively $0.06 \mathrm{ppb}$ and $100 \mathrm{ppb}$. The same type of instrument was used at all of the centres, and was calibrated at 0 and $100 \mathrm{ppb}$ as recommended by the manufacturer.

$\mathrm{FE}_{\mathrm{NO}}$ was measured in accordance with international guidelines [6]. Briefly, after inhaling to total lung capacity, the subjects exhaled through a mouthpiece equipped with a $0.2-\mu \mathrm{m}$ pore size bacterial filter into an exhalation circuit consisting of an ultrasonic flow meter, one-way valve and one sampling port. NO was sampled directly in the analyser (at a flow rate of $250 \mathrm{ml} / \mathrm{min}$ ) through a Teflon side arm tube attached to the sampling port. The sampling tube was $60 \mathrm{~cm}$ long with an internal diameter of $1 / 8$ of in. Both expiratory flow and $\mathrm{FE}_{\mathrm{NO}}$ values were simultaneously displayed on a computer attached to the analyser. $\mathrm{FE}_{\mathrm{NO}}$ was measured before the subjects underwent spirometry.

Different expiratory flow rates were ensured by placing expiratory resistors (Breath kit, Sievers Instruments, USA) in the exhalation circuit, which yielded expiratory flow rates of 50, 100 and $200 \mathrm{ml} / \mathrm{s}$. The subjects were asked to exhale at a constant flow, which they could readily see displayed on the computer screen in the form of a bar that remained red until target flow was obtained, and then turned green; if the flow dropped below or increased above the desired range, the green bar changed back to red. Although the target expiratory flows were strictly controlled and maintained during the expiration, a tolerance of $\pm 10 \%$ was considered acceptable, and the exhalation continued until a stable plateau had been reached.

Three $\mathrm{FE}_{\mathrm{NO}}$ plateau measurements varying by $<10 \%$ were made at each flow rate, and the average value was recorded. As the subjects inhaled ambient air, its NO concentration was measured at the time of each test and, if high (>30 ppb), the data were discarded. The influence of ambient NO levels was further excluded by placing an NO-scrubbing filter in the inspiratory limb of the collection apparatus. The data were stored on a computer and analysed using NO analysis software.

\section{Spirometry}

The patients underwent spirometry using a spirometer connected to a computer for data analysis (Vmax 22, Sensor Medics, Yorba Linda, CA, USA), and $\mathrm{FEV}_{1}$ and FVC were measured in accordance with the ATS standard procedure [8].

\section{Data analyses}

We first analysed the three subgroups of subjects from each centre and then all of the subjects as a whole. As there was no significant difference between the two analyses, for the sake of simplicity, we shall here describe only the results of the first.

Spearman's correlation test was used to verify the correlations between the variables. Between-group comparisons were made using non-parametric analysis of variance (Kruskal-Wallis test) and, if significant, the Mann-Whitney $\mathrm{U}$ test (M-W test). Logarithmic transformation was 
applied to the NO values in order to normalise the curve and the groups were compared using ANOVA; however, in order to simplify the reading, the data are presented as their original values and analysed non-parametrically. Bonferroni's correction for multiple tests was applied.

In the multivariate analysis of the odds ratio estimates, logistic regression was carried out backwise with preassigned $P$ values of $>0.05$ controlling step removal; the model was evaluated using three goodness-of-fit chisquare statistics.

All of the analyses were made using SPSS Rel. 13.0 statistical package (SPSS Inc., Chicago, IL).

\section{Results}

Table 1 shows the demographic data, physical and spirometric parameters, and $\mathrm{FE}_{\mathrm{NO}}$ values. The demographic data, physical parameters, and mean spirometric and $\mathrm{FE}_{\mathrm{NO}}$ values of the healthy non-smoking subjects studied in the three centres were pooled as there were no significant between-centre differences (data not shown).

Table 2 shows the distribution of the $\mathrm{FE}_{\mathrm{NO}}$ values. Of the 204 recruited subjects (male/female ratio $=1), 78(38 \%)$ were aged 19-30, 65 (32\%) were aged 31-40, 39 (19\%) were aged $41-50$, and 22 (11\%) were aged 51-60 years. There was no significant difference in age between the sexes.
All of the subjects underwent spirometry and $\mathrm{FE}_{\mathrm{NO}}$ measurement at an exhaled flow of $50 \mathrm{~mL} / \mathrm{s}$, and respectively 178 (92 men and 86 women) and 179 subjects (93 men and 86 women) also had $\mathrm{FE}_{\mathrm{NO}}$ measured at the exhaled flows of 100 and $200 \mathrm{~mL} / \mathrm{s}$. Twenty-five of the 26 subjects who were unable to perform the $\mathrm{FE}_{\mathrm{NO}}$ procedure at the exhaled flow of $200 \mathrm{~mL} / \mathrm{s}$ were also unable to do so at 100 $\mathrm{mL} / \mathrm{s}$.

There were significant gender-related differences in body mass index (BMI), height, weight and body surface area (BSA), forced expiratory volume at the first second $\left(\mathrm{FEV}_{1}\right)$, and forced vital capacity (FVC), but no gender-related difference in exhaled flow values.

At all of the studied flow, $\mathrm{FE}_{\mathrm{NO}}$ levels were significantly lower in the women than in the men (Table 1). $\mathrm{FE}_{\mathrm{NO}}$ levels did not correlate with age, lung function or anthropometric values.

There was a positive correlation between the $\mathrm{FE}_{\mathrm{NO}}$ values at the different exhaled flows: $\mathrm{FE}_{\mathrm{NO}} 50$ vs. $\mathrm{FE}_{\mathrm{NO}} 100 \mathrm{r}=$ $0.82, \mathrm{p}<0.001 ; \mathrm{FE}_{\mathrm{NO}} 50$ vs. $\mathrm{FE}_{\mathrm{NO}} 200 \mathrm{r}=0.74, \mathrm{p}<0.001$; $\mathrm{FE}_{\mathrm{NO}} 100$ vs. $\mathrm{FE}_{\mathrm{NO}} 200 \mathrm{r}=0.9, \mathrm{p}<0.001$.

$\mathrm{FE}_{\mathrm{NO}}$ levels were not correlated with age $(\mathrm{r}=0.1, \mathrm{p}=0.21$, Spearman's test) or with lung function or anthropometric values. $\mathrm{FE}_{\mathrm{NO}}$ levels at all studied flows were significantly lower in females than those observed in men (Table 1).

Table I: Demographic data, physical parameters and $\mathrm{FE}_{\mathrm{NO}}$ values in studied subjects. Mean values and standard deviation (SD).

\begin{tabular}{|c|c|c|c|c|c|c|c|c|c|}
\hline & \multicolumn{2}{|c|}{ Males } & \multicolumn{2}{|c|}{ Females } & \multicolumn{2}{|c|}{ Total } & \multicolumn{2}{|c|}{ Values } & \multirow[t]{2}{*}{$P$ value* } \\
\hline & No. & Value & No. & Value & No. & Value & Min & $\operatorname{Max}$ & \\
\hline Age (yrs) & 102 & $37.0 \pm 9.5$ & 102 & $35.0 \pm 10.1$ & 204 & $36.1 \pm 9,9$ & 19 & 59 & n.s. \\
\hline Weight (kg) & 102 & $77.6 \pm 12.2$ & 102 & $59.9 \pm 9.8$ & 204 & $68.8 \pm 14.2$ & 44 & 112 & 0.001 \\
\hline Height $(\mathrm{cm})$ & 102 & 176 & 102 & 164 & 204 & 170 & 148 & 190 & 0.001 \\
\hline $\mathrm{BMI}\left(\mathrm{m} / \mathrm{kg}^{2}\right)$ & 102 & 25.1 & 102 & 22.2 & 204 & 23.7 & 17.2 & 35.4 & 0.001 \\
\hline $\operatorname{BSA}\left(m^{2}\right)$ & 102 & 1.7 & 102 & 1.5 & 204 & 1.6 & 1.3 & 2.1 & 0.001 \\
\hline $\begin{array}{l}\mathrm{FE}_{\mathrm{NO}} 50 \\
(\mathrm{ppb})\end{array}$ & 102 & $11.7 \pm 5.0$ & 102 & $9.9 \pm 4.3$ & 204 & $10.8 \pm 4.7$ & 0.7 & 28.8 & 0.01 \\
\hline $\begin{array}{l}\mathrm{FE}_{\mathrm{NO}} 100 \\
(\mathrm{ppb})\end{array}$ & 92 & $7.1 \pm 3.0$ & 86 & $5.6 \pm 2.5$ & 178 & $6.4 \pm 2.9$ & 1.7 & 16.9 & 0.001 \\
\hline $\begin{array}{l}\mathrm{FE}_{\mathrm{NO}} 200 \\
(\mathrm{Ppb})\end{array}$ & 93 & $4.4 \pm 2.0$ & 86 & $3.5 \pm 1.4$ & 179 & $4.0 \pm 1.8$ & 0.9 & 10.7 & 0.001 \\
\hline FVC (litres) & 102 & $5.2 \pm 0.8$ & 102 & $3.8 \pm 0.5$ & 204 & $4.5 \pm 1.0$ & 2.3 & 7.1 & 0.001 \\
\hline $\begin{array}{l}\text { FVC } \% \\
\text { predicted }\end{array}$ & 102 & $108.3 \pm 12.7$ & 102 & $109.8 \pm 12.3$ & 204 & $109.1 \pm 12.5$ & 79 & 147.4 & n.s. \\
\hline $\begin{array}{l}\text { FEV (litres/ } \\
\text { I sec) }\end{array}$ & 102 & $4.2 \pm 0.6$ & 102 & $3.2 \pm 0.4$ & 204 & $3.7 \pm 0.7$ & 2.0 & 5.8 & 0.001 \\
\hline $\begin{array}{l}\mathrm{FEV}_{1} \% \\
\text { predicted }\end{array}$ & 102 & $105.7 \pm 11.5$ & 102 & $107.3 \pm 9.3$ & 204 & $106.5 \pm 10.5$ & 78 & 133.7 & n.s. \\
\hline
\end{tabular}

Abbreviations: $n$.s. $=$ not significant; FENO $50=$ fractional exhaled nitric oxide in parts per billion (ppb) at an expiratory flow of $50 \mathrm{~mL} / \mathrm{sec} ; \mathrm{FENO}$ $100=$ fractional exhaled nitric oxide in parts per billion (ppb) at an expiratory flow of $100 \mathrm{~mL} / \mathrm{sec}$; FENO $200=$ fractional exhaled nitric oxide in parts per billion (ppb) at an expiratory flow of $200 \mathrm{~mL} / \mathrm{sec}$; FEVI = forced expiratory volume (litres) in one second; FVC = forced vital capacity (litres); $\mathrm{BMI}=$ body mass index; $\mathrm{BSA}=$ body surface area; Min = minimum value; Max = maximum value

* Mann-Whitney U-test comparing male and female subjects 
Table 2: Data distribution of fractional exhaled nitric oxide values.

\begin{tabular}{|c|c|c|c|c|c|c|c|c|c|c|c|c|c|c|c|}
\hline \multicolumn{2}{|c|}{$\begin{array}{l}\mathrm{FE}_{\mathrm{NO}} \mathrm{Ppb} \\
\text { percentile }\end{array}$} & \multirow{2}{*}{$\begin{array}{c}\begin{array}{c}\text { Total } \\
\text { cases }\end{array} \\
102\end{array}$} & \multirow{2}{*}{$\begin{array}{l}5^{\text {th }} \\
4.5\end{array}$} & \multirow{2}{*}{$\begin{array}{l}10^{\text {th }} \\
5.5\end{array}$} & \multirow{2}{*}{$\begin{array}{l}20^{\text {th }} \\
7.3\end{array}$} & \multirow{2}{*}{$\begin{array}{l}25^{\text {th }} \\
8.6\end{array}$} & \multirow{2}{*}{$\begin{array}{l}30^{\text {th }} \\
9.0\end{array}$} & \multirow{2}{*}{$\begin{array}{c}40^{\text {th }} \\
10.3\end{array}$} & \multirow{2}{*}{$\begin{array}{l}50^{\text {th }} \\
11.4\end{array}$} & \multirow{2}{*}{$\begin{array}{l}60^{\text {th }} \\
12.5\end{array}$} & \multirow{2}{*}{$\begin{array}{l}70^{\text {th }} \\
13.8 \\
\end{array}$} & \multirow{2}{*}{$\begin{array}{l}75^{\text {th }} \\
14.4\end{array}$} & \multirow{2}{*}{$\begin{array}{l}80^{\text {th }} \\
15.1\end{array}$} & \multirow{2}{*}{$\begin{array}{l}90^{\text {th }} \\
19.2\end{array}$} & \multirow{2}{*}{$\begin{array}{l}95^{\text {th }} \\
20.6\end{array}$} \\
\hline $\mathrm{FE}_{\mathrm{NO}} 5$ & Males & & & & & & & & & & & & & & \\
\hline & $\begin{array}{c}\text { Femal } \\
\text { es }\end{array}$ & 102 & 3.6 & 4.5 & 5.5 & 6.0 & 7.1 & 8.7 & 9.7 & 10.8 & 12.0 & 13.1 & 13.6 & 16.2 & 18.2 \\
\hline & Total & 204 & 3.8 & 5.0 & 6.2 & 7.3 & 8.2 & 9.4 & 10.4 & 11.7 & 13.1 & 13.7 & 14.5 & 17.3 & 19.7 \\
\hline \multirow{3}{*}{$\begin{array}{c}\mathrm{FE}_{\mathrm{NO}} \mathrm{I} \\
00\end{array}$} & Males & 92 & 2.8 & 3.4 & 4.1 & 4.6 & 5.3 & 6.0 & 6.8 & 7.6 & 8.4 & 9.0 & 9.7 & 11.5 & 12.8 \\
\hline & $\begin{array}{c}\text { Femal } \\
\text { es }\end{array}$ & 86 & 2.2 & 2.6 & 3.3 & 3.7 & 4.0 & 4.8 & 5.4 & 6.0 & 6.7 & 7.4 & 8.0 & 9.6 & 10.3 \\
\hline & Total & 178 & 2.4 & 3.0 & 3.8 & 4.1 & 4.6 & 5.4 & 6.0 & 6.8 & 7.7 & 8.1 & 8.8 & 10.4 & 11.7 \\
\hline \multirow{3}{*}{$\begin{array}{c}\mathrm{FE}_{\mathrm{NO}^{2}} \\
00\end{array}$} & Males & 93 & 1.6 & 2.1 & 2.6 & 2.9 & 3.2 & 3.6 & 4.1 & 4.9 & 5.5 & 5.8 & 6.3 & 6.9 & 8.3 \\
\hline & $\begin{array}{c}\text { Femal } \\
\text { es }\end{array}$ & 86 & 1.6 & 1.8 & 2.2 & 2.4 & 2.6 & 3.1 & 3.3 & 3.7 & 4.0 & 4.1 & 4.6 & 5.5 & 5.9 \\
\hline & Total & 179 & 1.6 & 1.9 & 2.5 & 2.6 & 2.9 & 3.3 & 3.6 & 4.1 & 4.7 & 5.2 & 5.5 & 6.6 & 7.1 \\
\hline
\end{tabular}

Abbreviations: $\mathrm{FE}_{\mathrm{NO}} 50=$ fractional exhaled nitric oxide at an expiratory flow of $50 \mathrm{~mL} / \mathrm{sec}$; $\mathrm{FE}_{\mathrm{NO}} 100=$ fractional exhaled nitric oxide at an expiratory flow of $100 \mathrm{~mL} / \mathrm{sec} ; \mathrm{FE}_{\mathrm{NO}} 200=$ fractional exhaled nitric oxide at an expiratory flow of $200 \mathrm{~mL} / \mathrm{sec}$; $\mathrm{Ppb}=\mathrm{parts}$ per billion

Logistic regression analysis was performed considering sex as dependent variable and centre, weight, height, age, FEV1, FVC, $\mathrm{FE}_{\mathrm{NO}} 50, \mathrm{FE}_{\mathrm{NO}} 100$ and $\mathrm{FE}_{\mathrm{NO}} 200$ as potentially predictive factors.

Weight and FVC were identified as predictive variables able to distinguish between males and females (data not reported).

\section{Discussion}

The primary aim of this study was to measure $\mathrm{FE}_{\mathrm{NO}}$ in a population of healthy controls aged 19-65 years at a flow rate of $50 \mathrm{~mL} / \mathrm{s}$ using the on-line single breath technique.

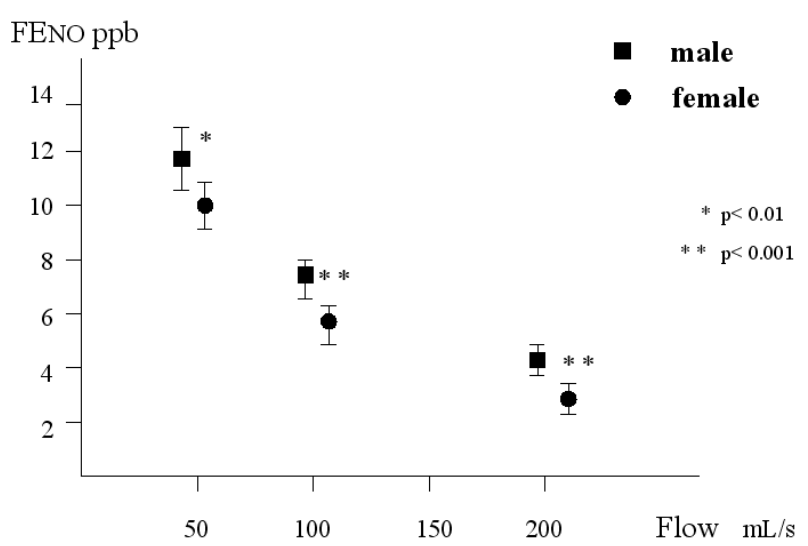

Figure I

Fractional exhaled nitric oxide $\left(\mathrm{FE}_{\mathrm{NO}}\right)$ levels in men and women at three expiratory flows. Mean values and $95 \%$ confidence intervals.
We also analysed $\mathrm{FE}_{\mathrm{NO}}$ at flow rates of 100 and $200 \mathrm{~mL} / \mathrm{s}$ in order to obtain their normal $\mathrm{FE}_{\mathrm{NO}}$ values, and compare the ability of normal adults to expire at such different flows.

The main finding was that, even after adjusting for age, height, weight, BMI and BSA, $\mathrm{FE}_{\mathrm{NO}}$ values were significantly lower in women at all of the studied expiratory flows, which means that different gender-related reference values need to be applied.

$\mathrm{FE}_{\mathrm{NO}}$ levels at the most frequently used expiratory flow rate of $50 \mathrm{ml} / \mathrm{s}$ was $2.6-28.8 \mathrm{ppb}$ in men and 1.6-21.5 $\mathrm{ppb}$ in women. The $\mathrm{FE}_{\mathrm{NO}}$ levels at $50 \mathrm{ml} / \mathrm{s}$ usually reported in studies of healthy adults fall within the 10-20 ppb range [9] but, as in the case of other biological parameters, we observed some individuals with unexplained higher or lower levels despite our strict study inclusion and exclusion criteria. It may therefore be more prudent to define normal $\mathrm{FE}_{\mathrm{NO}}$ values in terms of percentiles, and we would suggest considering the fifth and $95^{\text {th }}$ percentiles (4.5-20.6 ppb for males, and 3.6-18.2 ppb for females), as references for healthy subjects, and taking further diagnostic and clinical steps in the case of subjects whose $\mathrm{FE}_{\mathrm{NO}}$ levels fall outside this range.

Gender-related differences in adult $\mathrm{FE}_{\mathrm{NO}}$ levels were first reported by Jilma et al.[10], who examined the concentrations of exhaled NO and plasma nitrate, and were confirmed by Tsang et al.[11] in a cohort of 121 healthy nonsmoking subjects, and by van der Lee et al.[12] However, our data were collected in accordance with the most recent guidelines. It is not clear why this difference exists, but 
Grasemann et al.[13] have shown that it is partly associated with the NO synthase 1 genotype in healthy females; factors related to hormone production are less plausible, as Morris et al.[14] have shown that there is no temporal relationship between the measurements of NO production and urinary sex steroid conjugates during the menstrual cycle, thus suggesting that estrogens do not modulate $\mathrm{FE}_{\mathrm{NO}}$ concentrations.

We speculate that a further possible reason is the difference in airway surface area and calibre $[15,16]$. The same flow rate in airways of different calibres may differently dilute NO, which moves by means of gaseous diffusion into a smaller lumen (i.e. in females), thus leading to a lower NO concentration. Brooks et al.[17] have demonstrated that there is no within-gender correlation between tracheal size and body size or maximal expiratory flows, thus suggesting that the differences in the airway sizes of men and women are true gender-related difference and not simply due to differences in lung or body size. This hypothesis is in line with the findings of Buchvald et al. [7] showing no difference in $\mathrm{FE}_{\mathrm{NO}}$ levels between boys and girl of the same age, but a significant and positive relationship between $\mathrm{FE}_{\mathrm{NO}}$ and age (which leads to a progressive increase in airway surface) in both sexes; if the hypothesis is confirmed, it could be concluded that the low $\mathrm{FE}_{\mathrm{NO}}$ levels in women may simply be an artefact due to the use of a constant exhaled flow rate rather than a real reduction in NO airway production. In this regard, Nguyen et al. [18] have recently shown that the measurement of both $\mathrm{FE}_{\mathrm{NO}}$ and nitrogen oxides $\left(\mathrm{NO}_{\mathrm{X}}\right)$ in exhaled breath condensate is more indicative of airway $\mathrm{NO}$ production than $\mathrm{FE}_{\mathrm{NO}}$ alone; further studies should be carried out to verify whether there are any sexual differences in exhaled NOx.

Our data confirm that $\mathrm{FE}_{\mathrm{NO}}$ values are inversely related to the exhalation flow rate [19], and demonstrated that an exhaled flow of $50 \mathrm{~mL} / \mathrm{s}$ was feasible in all our subjects, which is in line with the published guidelines [6].

We also measured $\mathrm{FE}_{\mathrm{NO}}$ levels at higher expiratory flows of 100 and $200 \mathrm{ml} / \mathrm{s}$, because it has been suggested that extended exhaled NO measurements can distinguish alveolar and bronchial inflammation [20,21]. However, we found that there was a strong positive correlation $(\mathrm{r}=$ $>0.7$ ) between $\mathrm{FE}_{\mathrm{NO}}$ levels at different expiratory flows, and that it was not always possible to obtain reproducible expirations at higher flows in our healthy subjects. Further studies of large numbers of patients with proximal and distal airway inflammation should therefore be carried out in order to evaluate whether the $\mathrm{FE}_{\mathrm{NO}}$ measurements at different expiratory flow rates may lead to information that is as useful as that obtained at $50 \mathrm{ml} / \mathrm{s}$.
The mean $\mathrm{FE}_{\mathrm{NO}}$ levels at different expiratory flows in our subjects are comparable with those previously reported by some authors in healthy non-smoking subjects[18,21], but slightly lower than those reported by others, particularly those observed at the expiratory flow rate of $50 \mathrm{ml} / \mathrm{s}$ [23]. In this regard, Borrill et al.[24] have recently compared the $\mathrm{FE}_{\mathrm{NO}}$ levels measured using three different commercially available analysers and found significant differences between them. This raises the important question of variability between NO analysers. This is an important point as Muller et al. [25] have recently shown that the main factors responsible for the different NO readings provided by different analysers are differences in calibration gases and procedures. Our study was not intended to compare the NO readings provided by different analysers, but we are confident of the reliability of our results because Borrill et al. [24] found that the most reproducible data was that obtained using the CLD88, probably because it has the lowest detection limit and fastest response time, and because it is CE MDD approved and totally compliant to the standard required by the ATS/ERS recommendations.

In conclusion, our study demonstrated that measuring $\mathrm{FE}_{\mathrm{NO}}$ measurement at an expiratory flow rate of $50 \mathrm{ml} / \mathrm{s}$ was feasible in a population of 204 healthy subjects aged 19-65 years, and indicates that different normal $\mathrm{FE}_{\mathrm{NO}}$ values should be defined for males and females.

\section{Abbreviations}

ATS = American Thoracic Society

$\mathrm{CE} \mathrm{MDD}=$ European Community Medical Device Directive

$$
\begin{aligned}
& \mathrm{FE}_{\mathrm{NO}}=\text { fractional exhaled } \mathrm{NO} \\
& \mathrm{ERS}=\text { European Respiratory Society } \\
& \mathrm{NO}_{\mathrm{X}}=\text { nitrogen oxides } \\
& \mathrm{Ppb}=\text { parts per billion }
\end{aligned}
$$

\section{Competing interests}

The author(s) declare that they have no competing interest.

\section{Authors' contributions}

OM: substantial contribution to study conception and design, sample collection, data acquisition, analysis and interpretation; involved in drafting the article.

GT: substantial contribution to study conception and design, data analysis and interpretation, critically reviewing the draft for important intellectual content. 
MC: substantial contribution to study conception and design, sample collection; involved in drafting the articles.

LP: substantial contribution to study conception and design, data interpretation and statistical analysis; involved in drafting the article; final approval of the version to be published.

AM: substantial contribution to study conception and design, data interpretation and statistical analysis; involved in drafting the article; final approval of the version to be published.

CT: substantial contribution to study conception and design, data interpretation and statistical analysis; involved in drafting the article; final approval of the version to be published.

MM: substantial contribution to study conception and design, sample collection, critically reviewing the draft for important intellectual content.

\section{Acknowledgements}

We would like to thank Olga Acampa, Lucia Dalle Vedove and Beatrice Ragnoli for their valuable contribution in subject recruitment.

\section{References}

I. Gustafsson LE, Leone AM, Persson MG, Wiklund NP, Moncada S: Endogenous nitric oxide is present in the exhaled air of rabbits, guinea pigs and humans. Biochem Biophys Res Commun I99I, | 8 I:852-7.

2. Kharitonov SA: Exhaled markers of inflammatory lung diseases: ready for routine monitoring? Swiss Med Wkly 2004, 134: 175-92.

3. Kissoon N, Duckworth LJ, Blake KV, Murphy SP, Taylor CL, Silkoff PE: FE(NO): relationship to exhalation rates and online versus bag collection in healthy adolescents. Am J Respir Crit Care Med 2000, 162:539-45.

4. Ricciardolo FL, Sterk PJ, Gaston B, Folkerts G: Nitric oxide in health and disease of the respiratory system. Physiol Rev 2004, 84:73I-65.

5. Kharitonov SA, Barnes PJ: Biomarkers of some pulmonary diseases in exhaled breath. Biomarkers 2002, 7:1-32.

6. ATS/ERS Recommendations for standardized procedures for online and offline measurement of exhaled lower respiratory nitric oxide and nasal nitric oxide. 2005. Am J Respir Crit Care Med 2005, I 71:912-30.

7. Buchvald F, Baraldi E, Carraro S, Gaston B, De Jongste J, Pijnenburg MW, et al: Measurements of exhaled nitric oxide in healthy subjects age 4 to 17 years. J Allergy Clin Immunol 2005, I I5: I I30-6.

8. Clausen JL, Coates AL, Quanjer PH: Measurement of lung volumes in humans: review and recommendations from an ATS/ERS workshop. Eur Respir J 1997, 10:1205-6.

9. Silkoff PE, Carlson M, Bourke T, Katial R, Ögren E, Szefler SJ: The Aerocrine exhaled nitric oxide monitoring system NIOX is cleared by the US Food and Drug Administration for monitoring therapy in asthma. J Allergy Clin Immunol 2004, I | 4: | 24|-56.

10. Jilma B, Kastner J, Mensik C, Vondrovec B, Hildebrandt J, Krejcy K, Wagner $O$, et al.: Sex differences in concentrations of exhaled nitric oxide and plasma nitrate. Life Sci 1996, 58:469-76.

II. Tsang KW, Ip SK, Leung R, Yung E, Tipoe GI, Chan SL, Shum IH, et al.: Exhaled nitric oxide: the effects of age, gender and body size. Lung 200I, 179:83-9I.

12. van der Lee I, van den Bosch JM, Zanen P: Reduction of variability of exhaled nitric oxide in healthy volunteers. Respir Med 2002, 96:1014-20.
13. Grasemann H, van's Gravesande KS, Bûscher R, Drazen JM, Ratjen F: Effects of sex and of gene variants in constitutive nitric oxide synthases on exhaled nitric oxide. Am J Respir Crit Care Med 2003, 167: III3-6.

14. Morris NH, Sooranna SR, Steer PJ, Warren JB: The effect of the menstrual cycle on exhaled nitric oxide and urinary nitrate concentration. Eur J Clin Invest 1996, 26:48I-4.

15. Franklin PJ, Taplin R, Stick SM: A community study of exhaled nitric oxide in healthy children. Am J Respir Crit Care Med 1999, I59:3| I-4.

16. Latzin P, Beck J, Griese M: Exhaled nitric oxide in healthy children: variability and a lack of correlation with atopy. Pediatr Allergy Immunol 2002, 13:37-46.

17. Brooks LJ, Byard PJ, Helms RC, Fouke JM, Strohl KP: Relationship between lung volume and tracheal area as assessed by acoustic reflection. J Appl Physiol 1988, 64: 1050-4.

18. Nguyen TA, Woo-Park J, Hess M, Goins M, Urban P, Vaughan J, et al:: Assaying all of the nitrogen oxides in breath modifies the interpretation of exhaled nitric oxide. Vascul Pharmacol 2005, 43:379-84.

19. Silkoff PE, McClean PA, Slutsky AS, Furlott HG, Hoffstein E, Wakita S, et al:: Marked flow-dependence of exhaled nitric oxide using a new technique to exclude nasal nitric oxide. Am J Respir Crit Care Med 1997, 155:260-7.

20. Mahut B, Delacourt C, Zerah-Lancner F, De Blic J, Harf A, Delclaux $C$ : Increase in alveolar nitric oxide in the presence of symptoms in childhood asthma. Chest 2004, 125:10 I2-8.

21. Condorelli P, Shin HW, George SC: Characterizing airway and alveolar nitric oxide exchange during tidal breathing using a three-compartment model. J Appl Physiol 2004, 96: 1832-42.

22. Brindicci C, Ito K, Resta O, Pride NB, Barnes PJ, Kharitonov SA: Exhaled nitric oxide from lung periphery is increased in COPD. Eur Respir J 2005, 26:52-9.

23. Vints AM, Oostveen E, Eeckhaut G, Smolders M, De Backer WA: Time-dependent effect of nitrate-rich meals on exhaled nitric oxide in healthy subjects. Chest 2005, I 28:2465-70.

24. Borrill Z, Clough D, Truman N, Morris J, Langley S, Singh D: A comparison of exhaled nitric oxide measurements performed using three different analysers. Respir Med 2006 in press.

25. Muller KC, Jorres RA, Magnussen H, Holz O: Comparison of exhaled nitric oxide analysers. Respir Med 2005, 99:63I-7.

Publish with Bio Med Central and every scientist can read your work free of charge

"BioMed Central will be the most significant development for disseminating the results of biomedical research in our lifetime. "

Sir Paul Nurse, Cancer Research UK

Your research papers will be:

- available free of charge to the entire biomedical community

- peer reviewed and published immediately upon acceptance

- cited in PubMed and archived on PubMed Central

- yours - you keep the copyright

Submit your manuscript here:

http://www.biomedcentral.com/info/publishing_adv.asp
BiolMedcentral 